\title{
Getting to Gender Parity in a Top-Tier Mechanical Engineering Department: A Case Study
}

\section{Ms. Kath Xu, Massachusetts Institute of Technology}

Kath Xu is a Class of 2016 graduate of the Massachusetts Institute of Technology, where she studied mechanical engineering. She will join the Yale Law School Class of 2020 in the fall.

\section{Dr. Dawn Wendell, Massachusetts Institute of Technology}

Dr. Dawn Wendell is an engineer whose past projects range from BattleBots robots to medical devices, for which she holds several patents. She received four degrees from MIT including a PhD in Mechanical Engineering. She worked as a fluid mechanics researcher in Paris, France before returning to MIT as Assistant Director of Admissions. Currently Dr. Wendell works as a Senior Lecturer in MIT's Department of Mechanical Engineering teaching design, manufacturing, and instrumentation.

\section{Dr. Andrea S. Walsh, Massachusetts Institute of Technology}

Andrea Walsh is a historical sociologist who specializes in the fields of women's and gender studies, rhetoric and communication and visual media. She teaches at Massachusetts Institute of Technology in the programs in Women's and Gender Studies and Writing and Comparative Media Studies. 


\title{
Getting to Gender Parity in a Top-Tier Mechanical Engineering Department: A Case Study
}

\begin{abstract}
Consistently ranked as home to one of the world's top engineering programs, the Massachusetts Institute of Technology is often seen as a model for its undergraduate education programs and research output. However, the school leads in another important way: the Institute also boasts one of the most gender-balanced STEM-oriented undergraduate student bodies in the world.
\end{abstract}

This study helps illuminate the ways in which the Department of Mechanical Engineering has reached near parity in its female undergraduate population: in 2016 , women comprised $49.5 \%$ of mechanical engineering majors. In contrast, women numbered less than a third of undergraduate mechanical engineering majors back in 2000. In 2016, a cross section of mechanical engineering faculty and staff was interviewed to evaluate how the department has changed over the past 15 years to make the place a much more welcoming program for women now. In addition to the faculty members, the MIT Dean of Admissions was interviewed to understand how the university selects the pool of available undergraduate women who choose to major in mechanical engineering in the first place. Quotes from interviewees are first contextualized, and then interspersed with insights from background research.

Thematic analysis of interviews reveals that the gender equality so far achieved by the department has been a result of very deliberate, enduring structural changes, (e.g., hiring processes), and a strong representation of proactive department members with high levels of self-efficacy. These members are aware of gender equity issues, believe in their ability to enact change, and are willing to devote the time and energy to do so. Different but complementary actions, from changing the way the admissions office recruits applicants to broadening the faculty hiring searches, have compounded over time to help produce the current state of near parity in the undergraduate population.

It is hoped that the findings in this paper can help other institutions adopt strategies that will lead to improved gender balance in their engineering programs.

\section{Introduction}

Each year that men continue to vastly outnumber women in the STEM fields is a year that fails to tap into the potential of half of our population. The stakes can be high: when engineers do not design with both genders in mind, preventable fatalities result. The first airbags, designed by an 
all-male team, killed women when the designers did not take into account women's smaller sizes and different body structures (Massey). For decades, doctors who did not realize that women and men exhibit different heart attack symptoms would misdiagnose women and send them home (Del Giudice).

What does it take to achieve the elusive fifty-fifty gender balance in engineering? Like the set of studies that come before this one, this study aims to bridge the gap between women's and men's experiences in engineering. This conference paper draws upon the findings in a 2016 Massachusetts Institute of Technology senior thesis (Xu).

\section{Background}

According to a 2015 report by the American Society for Engineering Education (ASEE), women earned $19.9 \%$ of engineering bachelor's degrees in the United States that year (Yoder). However, the percentage of degrees earned by women varies widely based on the engineering discipline. Mechanical engineering is the most popular bachelor's engineering degree in the U.S., claiming almost a quarter of all engineering degrees. However, only $13.2 \%$ of mechanical engineering bachelor's degrees went to women in the 2014-2015 year, making it one of the most gender-imbalanced engineering disciplines in the U.S. (Yoder).

This is not the case, however, at MIT. In the fall of 2016, women composed $49.5 \%$ of mechanical engineering majors, an unheard-of percentage among peer schools and large engineering programs. This figure, moreover, surpasses even MIT's current overall undergraduate ratio of $46.1 \%$ female ("Number of Women Students").

And this figure surpasses those of other engineering programs which traditionally skew heavily male as well, such as electrical engineering and computer science. Figure 1, which compares the undergraduate female percentages at MIT to the percentage of bachelor's engineering degrees awarded to women nationally, illustrates the striking progress made by MIT, and the mechanical engineering department in particular. 
Figure 1: The ratio of the female percentage in engineering departments at MIT to those nationally based on most recent statistics available (2016-2017 MIT statistics from "Number of Women Students," 2014-2015 national statistics from Yoder).

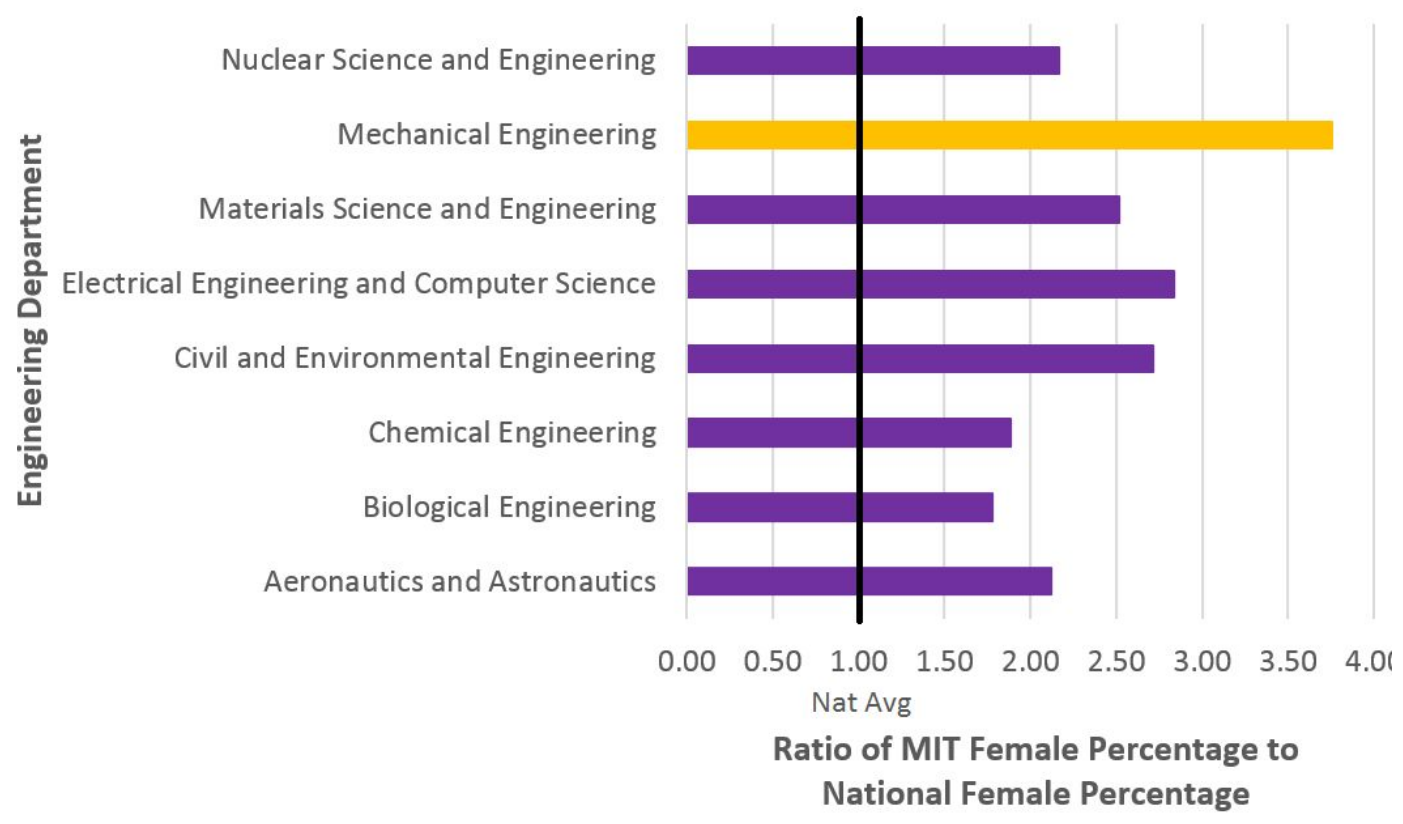

According to the MIT Registrar, women on average graduate with slightly higher grade point averages (GPAs) than males, even when controlling for the chosen major (Chin and Tekiela). ${ }^{1}$ Moreover, women's graduation rates have consistently exceeded those of men, as can be seen in Table 1.

Table 1: Six-year undergraduate MIT graduation rates by gender from Fall Cohort years 2003-2009 ("Retention and Graduation Rates").

\begin{tabular}{|l|l|l|l|l|l|l|l|}
\hline & \multicolumn{7}{|c|}{ Fall Cohort year } \\
\hline Gender & $\mathbf{2 0 0 3}$ & $\mathbf{2 0 0 4}$ & $\mathbf{2 0 0 5}$ & $\mathbf{2 0 0 6}$ & $\mathbf{2 0 0 7}$ & $\mathbf{2 0 0 8}$ & $\mathbf{2 0 0 9}$ \\
\hline Men & $90 \%$ & $91 \%$ & $91 \%$ & $92 \%$ & $91 \%$ & $90 \%$ & $90 \%$ \\
\hline Women & $93 \%$ & $96 \%$ & $95 \%$ & $93 \%$ & $95 \%$ & $92 \%$ & $95 \%$ \\
\hline
\end{tabular}

\footnotetext{
${ }^{1}$ Based on an analysis of final year GPAs between 2004 and 2011.
} 
While female undergraduates may have reached near parity in numbers, the story is very different for female faculty members. Figure 2 illustrates the percentage of female faculty at MIT in the School of Engineering and the School of Science over the past few decades.

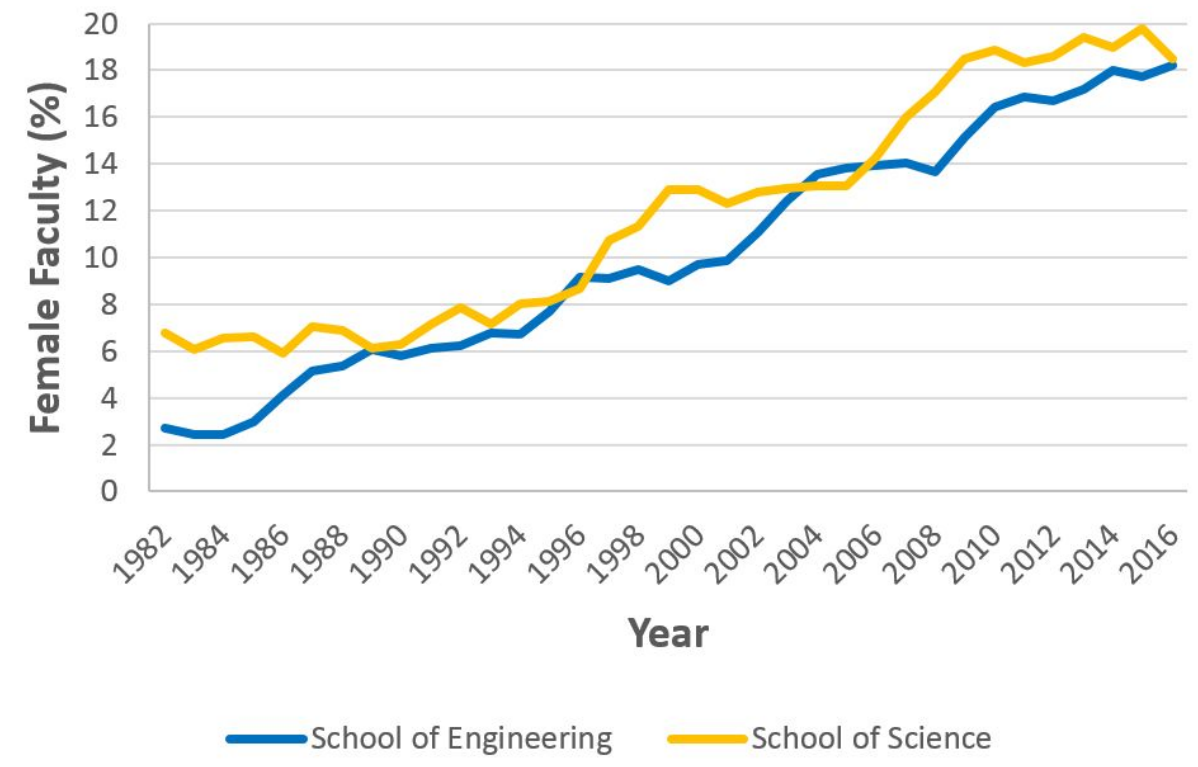

Figure 2: The percentage of female faculty at MIT in the School of Engineering and the School of Science (Xu). 2016 refers to Academic Year 2016-2017. All counts are based on the October census of each Academic Year.

The percentage of female engineering faculty at MIT has increased from $9.0 \%$ in Academic Year (AY) 1999-2000 to 18.2\% in AY 2016-2017, likely driven at least in part due to an internal report commissioned in 2002, titled the "Report of the School of Engineering," which highlighted the barriers that female faculty faced at MIT. The Institute's Mechanical Engineering Department hired its first female faculty member, Mary Boyce, in 1987 (Boyce et al. 12). According to former department head Rohan Abeyaratne, the MechE department used to be known as a department that was "unfriendly" to women.

While four other women were hired between 1987 and 2000, only Boyce remained at MIT past tenure (Boyce et al. 12). In 2002, the Committee on the Status of Women Faculty found that a "much higher percentage of female job candidates reject offers to come to MIT- $40 \%$ of women compared with $14 \%$ of the men offered jobs. Given MIT's status as one of the premier research universities in engineering in the world, these results are disturbing" (Boyce et al. 7). Discrepancies were also found in salary, compensation, and academic duties such as teaching loads and committee memberships. Now, in 2017, there are six female tenured professors in the mechanical engineering department ("Faculty Profiles"). 
While the percentage of undergraduate women at MIT as a whole has stayed fairly constant over the past 15 years, the percentage of undergraduate women in mechanical engineering has increased dramatically over the past decade and a half, from a low of 32.5\% in AY 2002-2003 to a record high of $49.5 \%$ in AY 2016-2017, as can be seen in Figure 3.

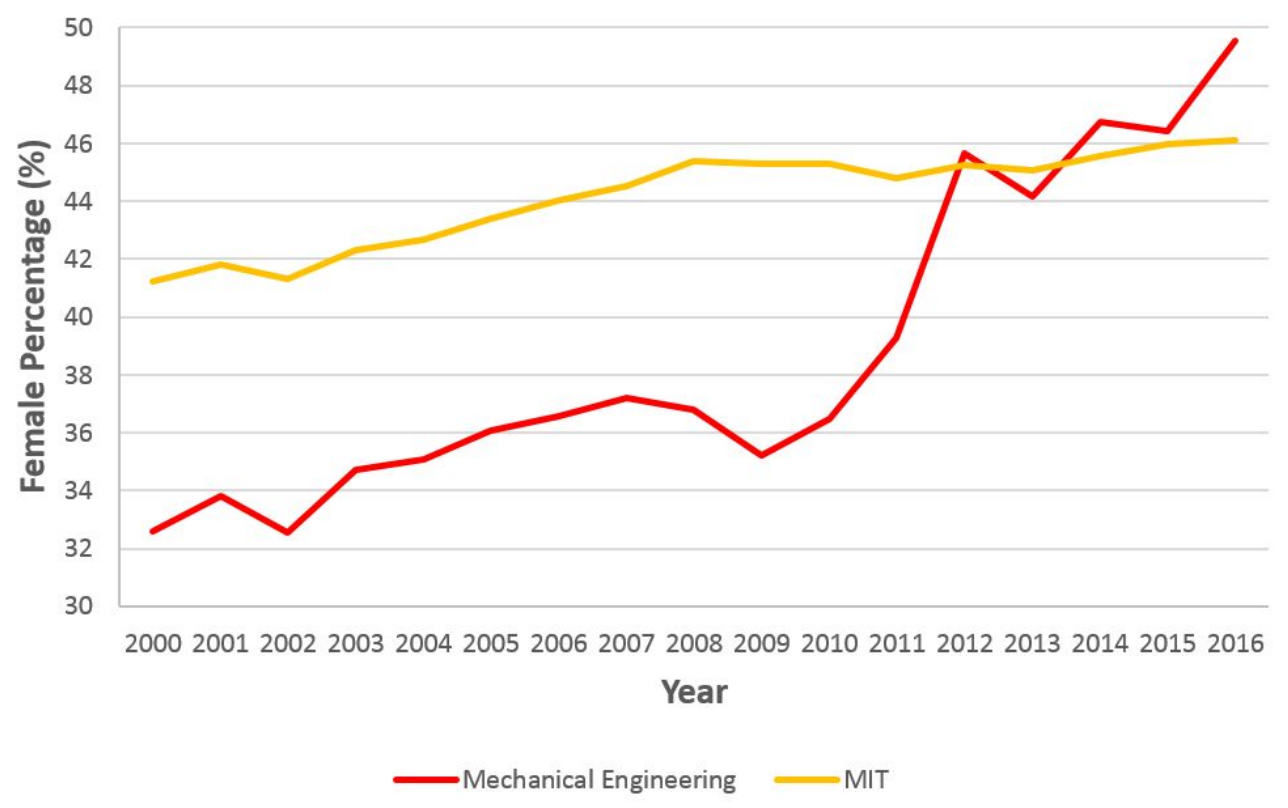

Figure 3: Percentage of undergraduate declared female majors (second-year, third-year, fourth-year, and fifth-year students) in the Department of Mechanical Engineering (2, 2A, and 2OE) over time, compared to the percentage of undergraduate female students at MIT. 2016 refers to Academic Year 2016-2017. All data taken from the annual October census.

The largest jump in the MechE department occurred over a four-year period between AY 2009-2010 and AY 2012-2013, with an increase from $35.2 \%$ to $45.7 \%$.

Furthermore, the percentage of declared female MechE majors in each graduating cohort has stayed relatively constant over the class members' three years in the major, as can be seen in Figure 4. 


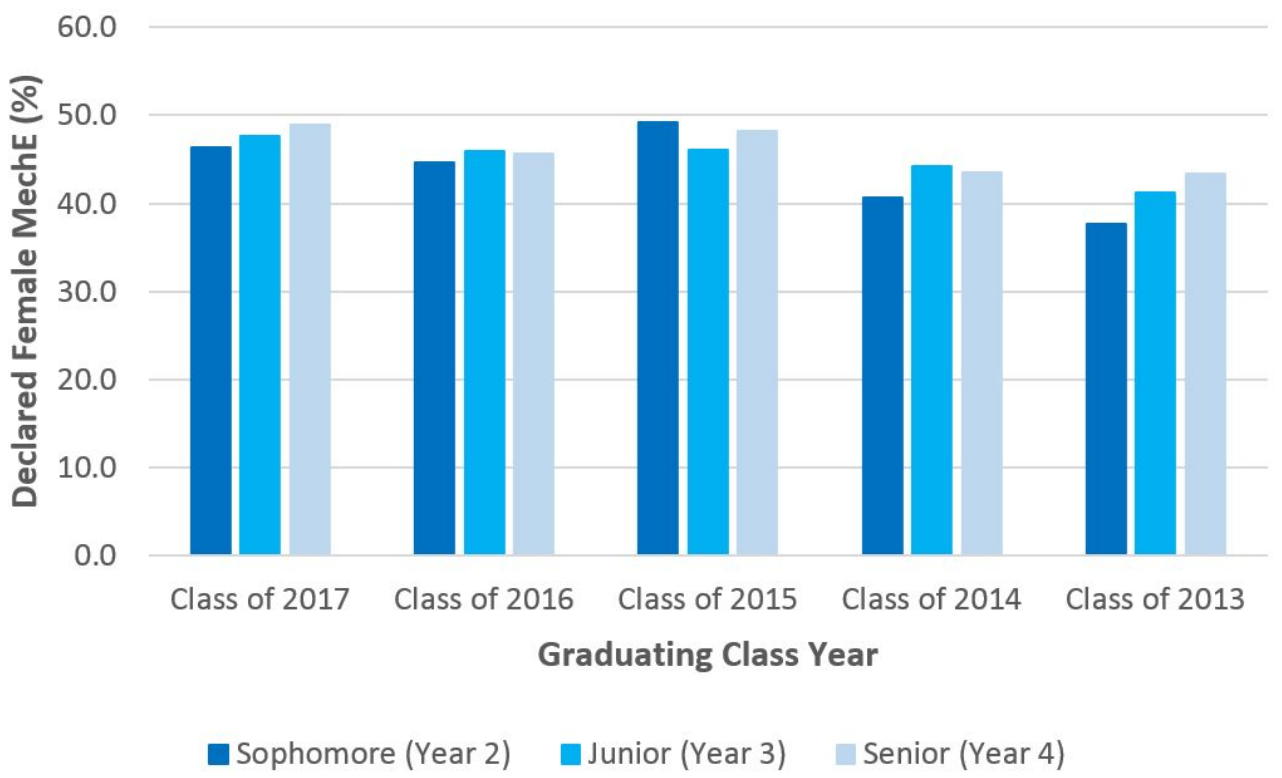

Figure 4: Percentage of undergraduate declared female majors in the Department of Mechanical Engineering (2, 2A, and 2OE) by class year and class standing. All data taken from the annual October census ("Number of Women Students"). ${ }^{2}$

It is very important to note that this jump at MIT does not reflect a national trend. In the Spring 2017 Term at the Georgia Institute of Technology, women compose only $27.4 \%$ of the total undergraduate mechanical engineering majors ("Enrollment by Major"), while women composed $35.4 \%$ of undergraduates in the fall term of 2015 (Georgia Institute of Technology). For the 2016-2017 academic year at the California Institute of Technology, women compose $40.9 \%$ of the total undergraduate population (Caltech), but only $34.8 \%$ of the total undergraduate mechanical engineering majors. ${ }^{3}$

What makes MIT different? How did MIT's mechanical engineering department get to where it is today? While student perspectives have been recently examined in other research at MIT (see Chin and Tekiela, Lim), this paper aims to help answer these questions through an examination of in-depth interviews with key members of the mechanical engineering department and the undergraduate admissions office.

\footnotetext{
${ }^{2}$ Freshmen are typically undeclared, and are thus not included in this figure.

${ }^{3}$ Many thanks to Debi Tuttle and Mary Morley from Caltech's Registrar Office for providing this information. A full data set for the 2015-2016 academic year is available with the original thesis.
} 


\section{Interview and Analysis Methods}

To better understand how gender dynamics in MIT's Mechanical Engineering Department have changed over the past decade and a half, a range of mechanical engineering faculty were interviewed on their thoughts from their own career paths in engineering to what they have observed at MIT to what they think could be done better in achieving gender balance in the field of mechanical engineering.

Ten MIT staff and tenure-track faculty members were interviewed for the original thesis. For the purpose of condensing the findings into this conference paper, only quotes from four interview subjects are included here.

Three of the four interviewees quoted in this paper are tenure-track faculty members, while the fourth heads MIT's undergraduate admissions office. Two of the interviewees are also alumni of the department. Their current positions, as listed by the Institute, can be found below. If they graduated from MIT, their degrees and degree years are also listed:

Anette (Peko) Hosoi-Associate Department Head MechE/Professor

Douglas (Doug) Hart SM '85-Professor

Rohan Abeyaratne-Quentin Berg Professor of Mechanics

Stuart (Stu) Schmill SB ’86-Dean of Admissions and Student Financial Services

Peko Hosoi was selected as the first female mechanical engineering associate department head, while Doug Hart came as a recommendation from Hosoi based on his results on the Harvard Gender-Science Implicit Association Test (a positive correlation between women and science). Rohan Abeyaratne, as former department head, hired Hosoi and many other female faculty members. Stu Schmill, as head of the undergraduate admissions department at MIT, exerts a large influence over who MIT admits, along with how MIT presents itself to potential minority applicants, which affects the pool of undergraduate students the mechanical engineering department can itself draw from.

Each person was interviewed once, with interview lengths ranging between half an hour to an hour. For each interviewee, a core set of questions was asked. (The full list of questions is available with the original thesis.) Selected quotes were carefully checked against the audio recordings. In addition, quote accuracy was confirmed with each interviewee before inclusion.

Keeping the core set of questions consistent made it possible to then conduct thematic analysis, the close comparative reading of the interview transcripts for common themes. Once identified, themes from the interviews were then connected to themes in the larger body of gender research. 
Quotes from interviewees are first contextualized, and then interspersed with commentary pulled from such research.

\section{Themes from Interviews}

This section covers four overarching topics: undergraduate admissions, role modeling, hiring, and awareness. A key message that emerged from each of the interviews was that the exceptional diversity in the mechanical engineering undergraduate population at MIT did not happen by accident. Rather, it took a concerted effort to diversify the department.

\section{Admission: Inspiring Women to Apply to and Enroll at MIT}

How and why the admissions office makes decisions on MIT's female applicants is important because it affects the pool of available women who can choose mechanical engineering. MIT has achieved great success in increasing its female undergraduate population. Undergraduate admission rates at MIT are low: 7.8 percent of applicants were admitted for the Class of 2020, 8.0 percent the year before, and 7.7 percent two years prior (Gopinath).

Through an interview with MIT's Dean of Admissions and mechanical engineering alumnus Stuart (Stu) Schmill, this subsection explores the undergraduate admissions process that helps produce one of the world's most gender-balanced undergraduate engineering populations.

A longstanding challenge in admitting minorities ${ }^{4}$ is the lack of a diverse pool in the first place. How, then, does MIT diversify its applicant pool?

One strategy the office uses when speaking at high schools is to highlight the gender balance at MIT as a means of cutting through stereotypes that a technical school like MIT would be female-unfriendly:

When we are out recruiting, we try to make sure [the gender balance is] well known. And of course, it's when students come to visit... we really try to make sure that they're aware of that. They see it while they're here. That's the hard part, though, for us... because we have to fight against conventional wisdom.

\footnotetext{
${ }^{4}$ Although women are not statistically a minority in the society at large, they are often considered a social minority group as they deal with similar barriers that statistical minorities like African-Americans face (Hacker). At MIT, women are often still both a social minority group and a statistical minority group.
} 
If you just take a random student, male or female, if they don't know much about us, they know MIT [as] this science, engineering [school]. They're going to think, "Oh, must be mostly men."

It's why most of what our recruitment... tries to humanize MIT. So if you think about our admissions website, what is the center of that? The blogs. ${ }^{5}$ It's the human voices, men and women... just describing what goes on here. That I think is like golden for us because the more people know about us, the more they like us. But we have a harder job communicating because we have to cut through these misperceptions that people have.

-Stu Schmill

Dean of Admissions

MIT also hosts several programs to encourage female high school students to enter STEM. One example is the Math Prize for Girls, an annual math competition for female high school students that offers the world's largest monetary math prize for women ("Math Prize for Girls").

Another example is the Women's Technology Program (WTP) at MIT, which began in 2002 with the Department of Electrical Engineering and Computer Science. The summer program, exclusively for high school girls, aims to encourage young women to pursue engineering and computer science studies and thus specifically targets smart students "who love and excel at math and science but have little or no background in engineering and computer science" (“WTP”).

We've been very supportive of the math department hosting on the MIT campus the Math Prize for Girls, for example. We're a big fan of the WTP program.

On our website, we certainly publicize them. When the students are here, we'll have admissions officers go and talk with them so that we know that there's a connection to them. And also, in the selection process, not that we give an advantage to those students, but we know that students who went through that program have demonstrated some type of interest.

-Stu Schmill

While the applicant pool as a whole self-selects, Schmill said he found that the female applicants in some ways self-select at a higher rate than their male counterparts do.

\footnotetext{
${ }^{5}$ The MIT Admission Blogs are a collection of blog posts written by undergraduate students about their lives at MIT.
} 
Most of the messages that we send about MIT are about not just how cool... the work is, but also about the fact that here at MIT, students and faculty work together to solve the big problems of the world and how you can come here and make a really big impact on the world.

So I think those messages resonate with young women as much as young men... I think that may account for the fact that we have a fairly robust applicant pool.

—Stu Schmill

Fewer women apply to MIT than men do: in the 2015-2016 admissions cycle, 12,750 men and 5,556 women applied (“Common Data Set 2015-2016”). 780 men and 739 women were admitted, leading some critics to contend that the admissions standards are lower for women than they are for men.

Yet, as mentioned in the background section, women graduate at higher rates and with slightly higher average GPAs than men do.

When we admit students, the metrics are the same, right. So male/female, there isn't a difference. But interestingly... women have higher graduation rates, right, from MIT... The students we're admitting are all equally academically and personally qualified and not just qualified, but are excellent. Because our applicant pool is so strong with enough very strong women applicants... when we admit our class, it is not quite but has been nearly half women over the last few years and that's been great.

We're not trying to control that number [female to male undergraduate ratio]. I mean, if we were really trying to control it, we would just do it. Just get 50\%. But we're not really trying to do that. We're still reliant or dependent on the strength of the applicant pool.

-Stu Schmill

Encouraging women to apply and admitting them is only half the story-MIT also needs to convince them to come. According to an MIT Admissions blog post by Mikey Yang, the Associate Director of Admissions, the Class of 2020 saw a record-high yield of just over 74\%.

There are two things that really help us. One is that... most, I think like $85 \%$ plus or minus, of our students, major in science or engineering... I think that helps us with women who are interested in majoring in science and engineering. They realize that... if they come to MIT, they're more likely to be in classes with other women. Whereas if they attend other universities that are not so centered on science and engineering where 
there may be gender balance, but... their science and engineering classes are very heavily male. Because we have much better gender balance in our science and engineering programs than just about anywhere.

-Stu Schmill

MIT's Campus Preview Weekend, when admitted students are invited to visit campus to gauge their fit with the school, used to only be for women and underrepresented minorities. 1999 was the first year that saw an integrated Campus Preview Weekend, with all admitted students invited (Basu).

That's why I think our applicant pool is so robust and our yield is very good, meaning the students we admit will choose to come. And that's true compared to other schools, like liberal arts schools that have science and engineering. But also we do better compared to other more science and engineering-centered places, places like Caltech and Carnegie Mellon. There aren't too many other places that are quite like MIT, but Caltech is an example. We've had better gender balance than they have over time.

-Stu Schmill

Caltech has rapidly increased its undergraduate female percentage over the past few years. The current freshmen class, the Caltech Class of 2020, enrolled $44 \%$ women and $56 \%$ men. In contrast, just three years ago, the freshman class at the time and now the Class of 2017 saw a much larger gap: $35 \%$ women to $65 \%$ men ("Class Profile").

And I think it's because women are more likely to choose to want to come to MIT because we are [gender-balanced]. It's a chicken and egg cycle, right. But I think that really helps us, and I do think we're in a relatively privileged position. I think other universities would love to be able to replicate, but I think have a harder time.

—Stu Schmill

This "chicken and egg cycle" that Schmill references suggests that although schools that currently have low gender balances likely cannot use the strategy of advertising their gender ratios to attract more women, schools may find it progressively easier to attract women as their female enrollment rises.

\section{Role Modeling: An Existence Proof for Female Students}

The low female faculty percentage in MIT's engineering departments means that female engineering students may end up graduating with few, if any, female role models. Mentorship 
and role models have proven to be important in people's career development, but gender can play a role as well.

In his interview, former department head Rohan Abeyaratne gave an anecdote relating the first time the importance of having female faculty as role models truly sunk in.

One thing I remembered greatly soon after Peko was hired... show[ed] how unaware sometimes people [can be about the importance of mentors] - certainly that I was. When I would walk past the hallway, the number of female students who were going to her office hours or coming in and out or kind of gathering there was striking. And it sort of struck me that, you know, maybe some female students feel much more comfortable talking to female faculty members. And this whole idea around... mentors, you know, like role models - all of that really crystallized with [Peko Hosoi] and Yang Shao-Horn, ${ }^{6}$ with those two first hires. Like you could see that these role models were really important.

-Rohan Abeyaratne Mechanical Engineering Department Head 2001-2008

As the 2002 "Report of the School of Engineering" stated, "professors naturally want to work with students and colleagues they're comfortable with, and in the traditionally masculine world of engineering, that often means other men with similar backgrounds. Senior male professors tend to take young men under their wings, providing mentorship and access to informal research networks" (Boyce et al.).

In a 2008 interview with MIT's student newspaper, The Tech, Abeyaratne shared his parting thoughts on the importance of role modeling as he reflected on his tenure as department head (Sankar):

Notable among the increase in students is an increase in the number of female students in the department, Abeyaratne said. He speculates that this may relate to an increase in female faculty, who serve as role models for female students, he said.

After Abeyaratne stepped down in 2008, he was succeeded by Mary Boyce, who became the first female department head within the School of Engineering. She served from 2008 to 2013 and is now the Dean of Engineering at The Fu Foundation School of Engineering and Applied Science at Columbia University, breaking barriers again as the first woman to head the School.

\footnotetext{
${ }^{6}$ Rohan Abeyaratne hired six female faculty members during his tenure as department head: Peko Hosoi, Yang Shao-Horn, Carol Livermore, Kim Hamad-Schifferli, Evelyn Wang, and Maria Yang. Hosoi, Shao-Horn, Wang, and Yang are now tenured professors at MIT, while Livermore and Hamad-Schifferli are no longer with MIT.
} 
In 2015, the Department of Chemical Engineering at MIT became the second department within the School of Engineering to be headed by a woman with the appointment of Paula Hammond, who is also the first black person to hold the post (News Office).

In her interview, associate department head Peko Hosoi brought up the idea that "existence proofs" could be as important as role modeling for female students looking to go into engineering fields.

When we talk to undergrads, they are not looking necessarily for role models. They are looking for an existence proof (emphasis mine). They want to know, "If I go down this path, is there going to be a job for me?" And if they look up and there are no women, then they think, "There's probably not going to be a place for me here so maybe I should go somewhere else."

In that sense, I think it is important to have women in visible positions everywhere. So that undergrads don't limit themselves when they look at the field and think, "There are no women here. Maybe this isn't for me."

-Peko Hosoi

Mechanical Engineering Associate Department Head

In that respect, Hosoi herself is serving an important role as the current highest-ranked woman in the department and the first female associate department head.

\section{Hiring: Broadening the Search}

How, then, do women reach a position in which they become role models in the first place? As recently as 20 years ago, MIT's mechanical engineering department used to be a much less welcoming place for female faculty members. The authors of the 2002 "Report of the School of Engineering," for which almost all of the female faculty members in the School of Engineering at the time were interviewed, found that the Institute was "not a hospitable environment for many women faculty.",

Some women noted that they had never been "invited to give a presentation at annual departmental retreats" (despite presentations by junior men who had been with the department for less than two years), and lacked representation on influential committees (Boyce et al.).

\footnotetext{
${ }^{7}$ Mary C. Boyce, Penny Chisholm, Edward F. Crawley, Lorna J. Gibson (Chair), Karen K. Gleason, Nancy A. Lynch, and John B. Vander Sande authored the report as members of the Committee on the Status of Women Faculty.
} 
Moreover, some women "were asked to teach lower level undergraduate subjects rather than specialized graduate subjects relating to their own research" and "to change their teaching assignments more often than their male peers," making it more difficult to focus on their research (Boyce et al.).

As the report notes, marginalization compounds over time: "women who are not invited to be on influential departmental committees do not develop the experience needed to move on to higher level administrative positions" (Boyce et al.).

Moreover, percentage-wise, female doctoral candidates in the school received faculty offers only about half of the time that male doctoral candidates did. The authors also discovered that the few female faculty candidates who did receive offers ended up rejecting them at a far greater rate (40\%) than the male faculty candidates did (14\%), results that were characterized as "disturbing" given "MIT's status as one of the premier research universities in engineering in the world" (Boyce et al.).

Even the gender-blind family leave policy might have widened more gender inequities than it closed. Some women expressed concern that "some men who take the leave use it to further their careers (by traveling the world to give seminars promoting their research or to start companies) rather than to care for the new child" (Boyce et al.).

Finally, the 2002 "Report of the School of Engineering" found evidence that female engineering faculty at MIT were compensated less for their work than their male colleagues were: "over half the women full professors received substantial increases in their salary following a request for a salary review in 1995," suggesting that "the need for sudden corrections could be due to the chronic underevaluation of female faculty" (Boyce et al.). ${ }^{8}$

In his interview, Abeyaratne recounted his memories of the state of the mechanical engineering department's female faculty during the time of the report.

At that time, in the late 1990s, we had one female faculty member in this department... The department had a reputation for being unfriendly to female faculty at the time.

In fact, when I became department head, there was a search committee that, in addition to identifying an individual for the position, also highlighted one of the main items [areas] that [were] of importance to the future of the department... and they identified the lack of female faculty as their number one issue.

\footnotetext{
${ }^{8}$ These salary adjustments, however, still did not account for the full loss of salary due to retirement contribution losses, etc.
} 
After the 2002 "Report of the School of Engineering" was released, the Dean of Engineering at the time, Thomas Magnanti, decided to immediately take action based on these findings. He "enforced the affirmative action policy more strictly, personally reviewing applications from women candidates and turning back proposals to hire specific candidates from departments that [had] not searched sufficiently for women or given appropriate consideration to women candidates." The Dean also set a target to increase the female faculty percentage in the School of Engineering to $20 \%$ by $2010 .^{9}$

Abeyaratne recounted the techniques the department used in recruiting female talent:

There were two things we did. So one thing was that in those days, we were not that aggressive [not only in relation to women]... in getting people to apply to MIT, right. We would advertise and we would sit back and wait. And it's like, "We are MIT and of course people would [apply]."

One thing we did was to reach out [to recruit female talent]... Faculty would contact people we knew. We would, you know, ask department heads, like, "Are there strong women graduating? Can we talk to them? Can you encourage them to apply?"

Basically the way we did it was by increasing the pool of applicants of women. Because the pool, initially there weren't [many] women.

And so the other change we did was not to define jobs that way, but to broaden things. And so we started advertising [for example] in mechanics [rather than say in mechanics of polymers], right. And then you cast a much bigger net, right. So again, the pool of applicants increases... Because once you have applicants, then you don't make any difference in standards. But what we worked hard to do was to get more applicants.

Now it's even more. Now they advertise mechanical engineering. It's like anything. The motivation I think is slightly different there but still, it's a very wide net... Plus, I think the pipeline also is getting larger. There [are] more women getting PhDs and wanting to go into academia.

-Rohan Abeyaratne

During her interview, Hosoi recalled her own hiring process at MIT:

\footnotetext{
${ }^{9}$ Although this goal was not met, almost $18 \%$ of the engineering faculty as of 2017 is female.
} 
I answered the phone and the person on the line said, "Hi, this is Rohan Abeyaratne calling from the Department of Mechanical Engineering at MIT." I thought, "That's nice." And he said, "As you might know, we have a search going on." And I thought, "Hmmm. I knew there was a search two years ago when I applied...?" And then I thought, "Maybe he's going to ask me to send an updated CV." Instead, he says, "We'd like to make you an offer." I was like, "What??" There was no job interview. There was no chalk talk.

When I arrived at MIT, there were a lot of women who had been hired at the same time. At a junior women's faculty lunch, somebody asked, "How did you end up at MIT?" All of the answers were the same. "Somebody called and asked me to apply." "Somebody asked me to come." "Somebody called and asked me to..." Every single person in that room... All of us already had jobs somewhere else. None of us would have applied to MIT if somebody hadn't called us... and said, "Give MIT a try. Come on over." I think that completely changed the landscape.

Let's be honest; I don't know what happened when I got hired, but I probably would not have landed at MIT without equal opportunity hiring practices. To clarify; this is in no way a reflection of the imposter syndrome. I don't feel that I shouldn't be here. [Laughter] But I feel that to get somewhere like MIT, you have to get a little lucky (regardless of your gender). And there are so few women in the hiring pool that if you're going to rely on getting lucky to find good women, it's going to take a long time.

-Peko Hosoi

Hosoi's mention of the imposter syndrome refers to the "internal experience of intellectual phoniness that appears to be particularly prevalent and intense among a select sample of high achieving women," as defined by psychologists Pauline Rose Clance and Suzanne Imes in the first paper published on the subject in 1978 (Clance).

We need to understand what makes great women apply to one of our positions... for example, when they hired me and all of the other women who attended that junior women's faculty lunch, none of us would have applied. Zero. Out of a room full of women, zero would have applied. And that was because when I read the job announcement, I thought, "That doesn't sound like me." So there needs to be a way to write those job announcements in a way that women instead think, "I should apply." 
We're moving in that direction with a broad search. But even I-I had been a postdoc at MIT so I know and love MIT — and I didn't read that job announcement and think, "That sounds like me."

-Peko Hosoi

Hosoi then went on to relate an anecdote by a friend who starts companies:

I heard from a friend who has learned [from] hiring for his companies... that if you ask a woman, "Do you know Python?" and she doesn't know Python but feels confident she can learn Python, she will say, "No, I don't know Python, but I'm confident I can learn it." If you ask a man, "Do you know Python?" and he doesn't know Python but he's confident he can learn Python, he'll just say, "Yes." [Laughter] There are always subtle gender differences like that.

-Peko Hosoi

Like Abeyaratne, Professor Doug Hart was also involved with hiring in the mechanical engineering department at the time that these changes in the faculty search process took place.

There was a mandate that we had to give special consideration to any women applicants which means that we could turn them down, but we had to justify why we turned them down. Normally, we don't have to justify everything. In this case, well, if you got a minority... you have to do all this extra paperwork. So they were subtly forcing it, the issue, right. It was a mandate from the Dean of Engineering.

It was a policy change with the attempt to try to balance the enrollment. And they said... "If you get a good minority or women candidate that doesn't fit your search, yes, you can turn them down, but you should pass that person on to other searches within the university so they can look at them too."

The idea is... good candidates are hard to find. If you find a good candidate, you should at least let other people try to find it. And that should probably go for everything, but they mandated it for women and minorities.

—Doug Hart

Professor

However, not everyone was on board at the time. Hart cited one male faculty member who resisted this policy change because he did not think it truly reflected the values of a meritocracy. Hart, who has taught the 2.013/2.014 (Engineering Systems Design) sequence for half a decade, described his observations of gender dynamics in group work settings: 
Now that I've seen teams and startup companies work and teams working in my class and so forth, I believe that the group dynamics is probably as much or more important than any individual. It's nice to have superstars. Superstars don't always make for a good team. It's better to say, “Okay, I want superstars, but I want them to be able to work together."

-Doug Hart

Institutions have long grappled with the meaning of a meritocracy: when there has been a history of sexism and underrepresentation of women in the field, what should a meritocracy look like? MIT, and many other higher education institutions, answer with affirmative action policies in both its student admissions and faculty searches.

If the goal is to develop the best department in the world, that's essentially a team, and you need to take into account the fact that gender's part of that that you need to correct and represent everybody because our student body is very diverse in turn. I think it [the department]'s a lot healthier now.

—Doug Hart

Hart, as one of the male participants in the gender equality movement, follows a long line of male faculty members at MIT who cared and, most importantly, listened and acted upon disparities; this list includes former MIT President Charles "Chuck" Vest, former Dean of Science Robert J. Birgeneau, former mechanical engineering department head Rohan Abeyaratne, and more.

\section{Awareness: First Steps to Cultural Change}

As these interviews have illustrated, awareness of gender biases is the first step to addressing any kind of change. It is important to acknowledge not only explicit biases, but implicit biases as well. These are often harder to detect, and, as such, may be just as insidious. Harvard's Project Implicit currently offers 13 implicit association tests that help assess one's biases in topics ranging from race to religion to gender. According to the project's website, "the Implicit Association Test (IAT) measures attitudes and beliefs that people may be unwilling or unable to report" ("Project Implicit"). The gender-science one "often reveals a relative link between liberal arts and females and between science and males." After taking the test, survey participants are asked for demographic information to help inform research.

In a 2009 paper published in the Proceedings of the National Academy of Sciences of the USA (PNAS), researchers analyzed this data and found that "women who find it easier to associate 
men with science (and women with liberal arts) report less liking for math and science domains, less interest in pursuing science in the future, perform worse on standardized math exams like the SAT and ACT, and are less likely to be a math or science majors compared with women who do not have that association" (Nosek et al.).

This is significant because "about $70 \%$ of more than half a million Implicit Association Tests completed by citizens of 34 countries revealed expected implicit stereotypes associating science with males more than with females" (Nosek et al.).

I think being aware of gender bias is important. I think one way to start to grow awareness is to make everyone take the implicit bias test. We could recommend that everyone at MIT take the implicit bias test once a year. You don't have to tell anyone what your score is. You just need that level of self-awareness. [Laughter]

Let me tell you a funny story... I think this was in $2.001 .{ }^{10}$ I can't even remember [who] the student was. This was a male student who did not do well on the first exam. So I send out an email saying, "If you did not do well on the first exam, please come talk to me." So he did the right thing. He set up a meeting and came to talk to me. And I said, "What happened on the first exam?" And he said, "I don't know, I should have studied more." Then he said, "You know, I'm really embarrassed I did so badly on this exam. I looked at the exam of the person next to me and realized I did so badly that I was beat by a GIRL."

And I looked at him. I looked at him. I LOOKED at him. [Laughter] And then he started and said, "OH. Oh. Sorry!" And you could see the awareness dawning on his face. There's a level of self-awareness that people ought to have but may be lacking when they arrive. Which is fine. Students come to MIT out of high school with many different backgrounds and experiences. But this is something they should learn while they are at MIT if they have not already learned it. And I think that guy learned it. [Laughter]

-Peko Hosoi

\section{Conclusion}

Over the past two decades, the Mechanical Engineering Department at MIT has made great strides in increasing its representation of undergraduate women. MIT has far exceeded the national average and even other peer schools when it comes to balancing the gender enrollment early and consistently, both at the school overall and within the Mechanical Engineering Department. While $49.5 \%$ of MIT's MechE department is female, nationally, only $13.2 \%$ of

\footnotetext{
${ }^{10} 2.001$ (Mechanics and Materials I) is the introductory mechanical engineering class at MIT.
} 
MechE bachelor's degrees go to women (Yoder). This achievement should not be taken for granted.

Through interviews with faculty and staff members, it has become apparent that the department has taken strong, identifiable steps over the years to promote gender equality in MechE with the leadership of both women and men in positions of power.

Thematic analysis of interviews reveals that the gender equality so far achieved by the department has been a result of very deliberate structural changes, (e.g. hiring processes), and a strong representation of proactive department members with high levels of self-efficacy-they are both aware of gender issues and believe in their ability to enact change. Different but complementary actions, from changing the way the admissions office recruits admissions candidates to broadening the faculty hiring searches, have compounded over time to produce the current state of near parity in the undergraduate population. These actions may not have been coordinated, but, taken together, resulted in a culture shift that prioritized diversity and gave women a chance to thrive.

These background interviews have contextualized the department's remarkable rise in undergraduate female enrollment and can help inform future studies on the matter. Surveys and interviews with alumni, particularly from the years in which the undergraduate female enrollment in the mechanical engineering department spiked, are recommended to delve further into the students' perspectives of why the undergraduate mechanical engineering population has reached near parity, including the role, if any, that students themselves played in bringing about this change.

This study of the movement towards gender parity in MIT's mechanical engineering department has illustrated the impact of three key allies: (1) the university admission office and its commitment to diversifying the overall undergraduate population, (2) the departmental faculty hiring decision-makers and their willingness to enact changes in the search process, and (3) the administrators and faculty members who not only acknowledge the existence of gender biases, but also care enough to challenge the status quo. For any school, department, or individual who prioritizes achieving gender balance in the STEM fields, these findings should provide - as in the memorable words of one interviewee - an existence proof that this gender equality is not just possible, but possible today. 


\section{Works Cited}

Basu, Sanjay. "First Inclusive CPW Draws 784 Prefrosh." The Tech [Cambridge] 9 Apr. 1999: $\mathrm{n}$. pag. The Tech. Web. 26 Jan. 2017. <http://tech.mit.edu/V119/N18/18cpw.18n.html>.

Boyce, Mary C., Penny Chisholm, Edward F. Crawley, Lorna J. Gibson, Karen K. Gleason, Nancy A. Lynch, and John B. Vander Sande. Report of the School of Engineering. Rep. N.p.: n.p., n.d. Report of the School of Engineering. Committee on Women Faculty in the School of Engineering at MIT, Mar. 2002. Web. 26 Jan. 2017.

$<$ http://web.mit.edu/faculty/reports/pdf/soe.pdf $>$.

Caltech. "Fall Enrollment 2016-17." Office of the Registrar. Caltech, n.d. Web. 11 Feb. 2017. $<$ https://www.registrar.caltech.edu/academics/enrollment $>$.

Chin, Caroline, and Kamilla Tekiela. The Status of Undergraduate Women at MIT. Rep. N.p., Feb. 2016. Web. 26 Jan. 2017.

$<$ http://diversity.mit.edu/wp-content/uploads/ReportUndergradWomen.pdf $>$.

Clance, Pauline R. "The Imposter Phenomenon in High Achieving Women: Dynamics and Therapeutic Intervention." Psychology and Psychotherapy: Theory, Research and Practice 15.3 (1978): 241-47. PsycNet. American Psychological Association. Web. 26 Jan. 2017. $<$ http://psycnet.apa.org/journals/pst/15/3/241>.

"Class Profile." Class Profile. Caltech Undergraduate Admissions, n.d. Web. 26 Jan. 2017. $<$ https://www.admissions.caltech.edu/content/class-profile $>$.

"Common Data Set 2015-2016." MIT Office of the Provost. MIT Office of the Provost, Institutional Research, n.d. Web. 26 Jan. 2017. <http://web.mit.edu/ir/cds/2016/c.html>.

Del Giudice, Marguerite. "Why It's Crucial to Get More Women Into Science." National Geographic. National Geographic Partners, 8 Nov. 2014. Web. 11 Feb. 2017. $<$ http://news.nationalgeographic.com/news/2014/11/141107-gender-studies-women-scienti fic-research-feminist/>.

"Enrollment by Major." Enrollment by Major. Georgia Institute of Technology, 26 Jan. 2016. Web. 26 Jan. 2017. $<$ http://apps.irp.gatech.edu/apps/Enrollment/Major.cfm?TERM=201302\&time_status=\&F $\mathrm{TE}=0>$.

"Faculty Profiles." MechE Faculty. MIT Department of Mechanical Engineering, n.d. Web. 26 Jan. 2017. <http://meche.mit.edu/people>.

Georgia Institute of Technology. "Class Enrollment by Gender \& Ethnicity - Tables 4.18 \& 4.19." Georgia Tech Fact Book. Georgia Institute of Technology, 2015. Web. 11 Feb. 2017.

$<$ http://factbook.gatech.edu/admissions-and-enrollment/class-enrollment-by-gender-ethnici ty-table-4-18/>.

Gopinath, Divya. "MIT Admits 1,485 to Class of 2020." The Tech. N.p., 17 Mar. 2016. Web. 26 Jan. 2017. <http://tech.mit.edu/V136/N8/admissions.html>. 
Hacker, Helen M. "Women as a Minority Group." Social Forces 30.1 (1951): 60-69. Print.

Lim, Kirsten B. Understanding the Gender Differences in Factors Affecting the Decision to Study Engineering at MIT. Thesis. Massachusetts Institute of Technology, 2015. N.p.: n.p., n.d. DSpace@MIT. Web. 17 Mar. 2017. <https://dspace.mit.edu/handle/1721.1/98779>.

Massey, Tracey. "How a Background in STEM Can Drive Women to the Top." Forbes. Time Inc., 30 Nov. 2016. Web. 26 Jan. 2017.

$<$ http://fortune.com/2016/11/30/mars-chocolate-stem-women-business/>.

"Math Prize for Girls." Math Prize for Girls. Advantage Testing Foundation, n.d. Web. 26 Jan. 2017. <http://mathprize.atfoundation.org/index>.

News Office. "Paula Hammond Named Head of Department of Chemical Engineering." MIT News Office. MIT Office of Communications, 13 July 2015. Web. 26 Jan. 2017.

$<$ http://news.mit.edu/2015/paula-hammond-named-head-department-chemical-engineering $-0713>$.

Nosek, B. A., F. L. Smyth, N. Sriram, N. M. Lindner, T. Devos, A. Ayala, Y. Bar-Anan, R. Bergh, H. Cai, K. Gonsalkorale, S. Kesebir, N. Maliszewski, F. Neto, E. Olli, J. Park, K. Schnabel, K. Shiomura, B. T. Tulbure, R. W. Wiers, M. Somogyi, N. Akrami, B. Ekehammar, M. Vianello, M. R. Banaji, and A. G. Greenwald. "National Differences in Gender-science Stereotypes Predict National Sex Differences in Science and Math Achievement." Proceedings of the National Academy of Sciences 106.26 (2009): 10593-0597. National Academy of Sciences, 24 Apr. 2009. Web. 26 Jan. 2017. $<$ http://www.pnas.org/content/106/26/10593.full>.

"Number of Women Students by Course and Year." Enrollment Statistics. MIT Office of the Registrar, 7 Oct. 2016. Web. 26 Jan. 2017.

$<$ http://web.mit.edu/registrar/stats/gender/index.html $>$.

"Project Implicit." Project Implicit. N.p., n.d. Web. 26 Jan. 2017.

$<$ https://implicit.harvard.edu/implicit/selectatest.html $>$.

"Retention and Graduation Rates." Retention and Graduation Rates. MIT Office of the Provost, Institutional Research, n.d. Web. 26 Jan. 2017.

$<$ http://web.mit.edu/ir/pop/students/graduation_rates.html $>$.

Sankar, Ramya. "Head of Mechanical Engineering Dept. Will Leave His Post in July." The Tech. N.p., 9 May 2008. Web. 26 Jan. 2017. $<$ https://thetech.com/2008/05/09/abeyaratne-v128-n25>.

"WTP, the Women's Technology Program." Women's Technology Program. MIT EECS, n.d. Web. 26 Jan. 2017. <https://www.eecs.mit.edu/outreach/womens-technology-program>. Xu, Kathleen L. Getting to Gender Parity in the Mechanical Engineering Department at MIT. Thesis. Massachusetts Institute of Technology, 2016. N.p.: n.p., n.d. DSpace@MIT. Web. 11 Feb. 2017. <https://dspace.mit.edu/handle/1721.1/105654>. 
Yang, Mikey. "Class of 2020 Wait List Decisions." Blog post. MIT Admissions. MIT Admissions Office, 11 May 2016. Web. 26 Jan. 2017. $<$ http://mitadmissions.org/blogs/entry/class-of-2020-wait-list-decisions $>$. Yoder, Brian L. Engineering by the Numbers. Rep. American Society for Engineering Education, 2015. Web. 26 Jan. 2017. $<$ https://www.asee.org/papers-and-publications/publications/college-profiles/15Engineerin gbytheNumbersPart1.pdf $>$. 